\title{
Teatro expandido em contexto brasileiro
} Expanded theatre in Brazilian context

\section{Sílvia Fernandes}

Sílvia Fernandes

Professora titular do PPG em Artes Cênicas da Escola de Comunicações e Artes da Universidade de São Paulo (ECA-USP)

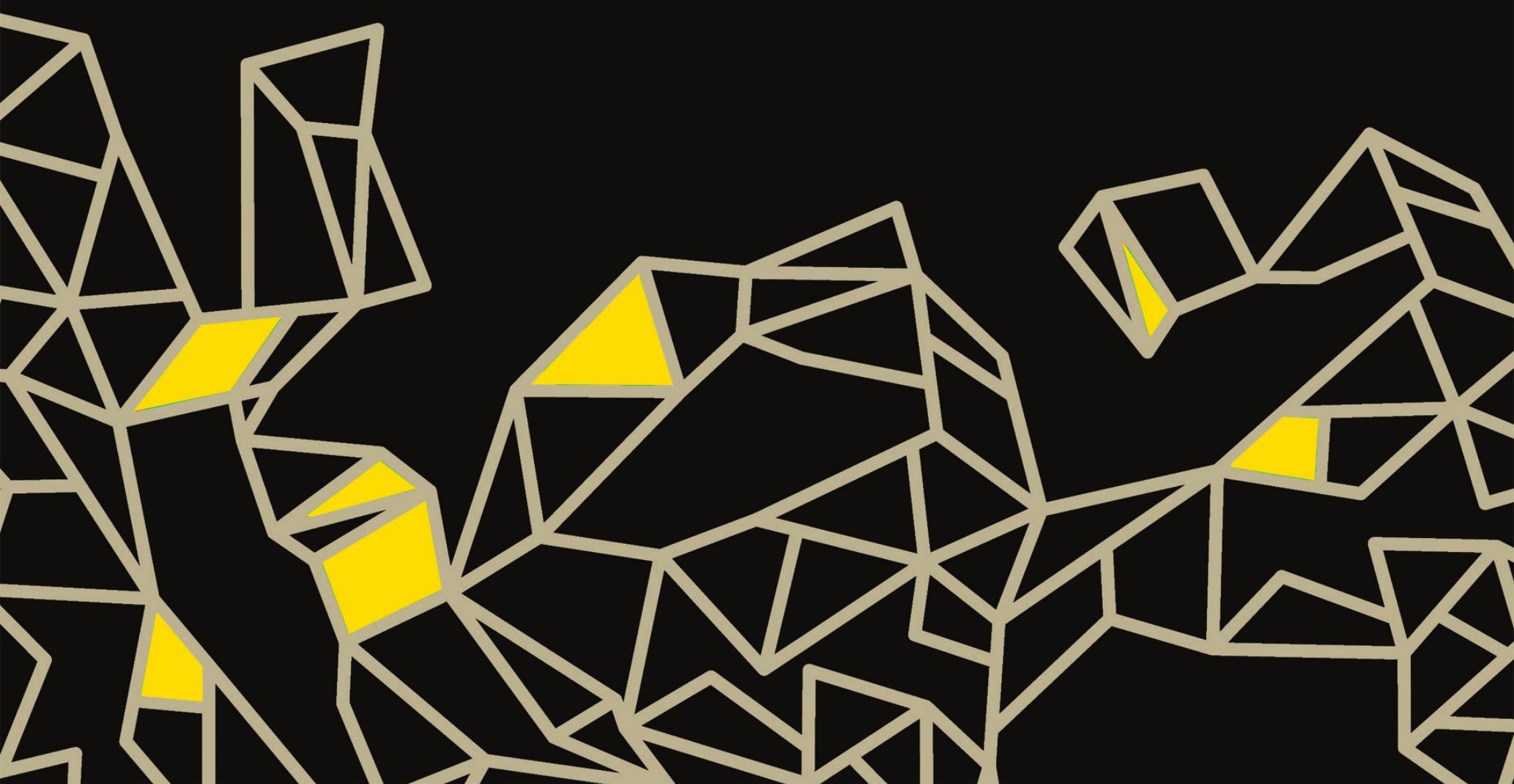




\section{Resumo}

O texto trata da retomada do ativismo nas instâncias da arte contextual (Paul Ardenne) e relacional (Nicolas Bourriaud), que se reflete na aproximação das artes cênicas com a política. Claire Bishop considera a tendência um "giro social" da arte, que localiza no final do século XX e detecta na postura social, característica dos criadores, e na rejeição à estética e à formalização, substituídas por intervenções decididamente ligadas ao trabalho em comunidades e à atuação em frentes próximas ao trabalho social. Na tentativa de reabilitar a ideia de estética em conexão com a política, Bishop recorre ao filósofo Jacques Rancière e a suas concepções de "partilha do sensível" e "regime estético da arte". A partir desses pressupostos, analisa-se o trabalho da artista Lia Rodrigues e sua relação com a comunidade da Maré.

Palavras-chave: Giro social da arte, Estética e política, Lia Rodrigues.

\section{Abstract}

The text deals with the resumption of activism in contextual (Paul Ardenne) and relational art (Nicolas Bourriaud) that is reflected in the approach between the performing arts and politics. Claire Bishop considers the movement a "social turn" of art, which she locates at the end of the 20th century and detects in the social posture, characteristic of the creators, and in the rejection of aesthetics and formalization, replaced by interventions decidedly linked to work in communities and acting in fronts close to social work. In an attempt to rehabilitate the idea of aesthetics in connection with politics, Bishop uses the philosopher Jacques Rancière and his conceptions of "distribution of the sensible" and "aesthetic regime of art."Based on these assumptions, the work of the artist Lia Rodrigues and her relationship with the community of Maré (Rio de Janeiro, Brazil) is analyzed.

Keywords: Social turn of art, Aesthetics and politics, Lia Rodrigues.

É recorrente a constatação de que o teatro, desde as últimas décadas do século $X X$, tem desafiado os paradigmas tradicionais ao criar experiências híbridas, descentradas, que parecem furtar-se a padrões de reconhecimento e leitura mais tradicionais.

O fenômeno não é novo. Desde as vanguardas históricas, do princípio do século $X X$, o lugar de ocorrência do teatro e o conceito que lhe dá visibilidade 
sofreram profundas alterações. Mas, sem dúvida, o deslocamento mais radical manifestou-se a partir dos anos 1960, quando artistas vindos preferencialmente das artes visuais e da música, como Allan Kaprow, John Cage ou Joseph Beuys criam gêneros teatrais híbridos, como o happening e a arte da performance.

São bastante conhecidas as teorizações que se dedicam à análise da desfronteirização das artes e de sua expansão para além das especializações, que se acentua a partir dos anos 1980. No campo teatral, foram indicadas, por exemplo, nos estudos de Erika Fischer-Lichte, que detecta um "giro performativo" no teatro, acentuado no final do século XX. Josette Féral refere-se ao mesmo fenômeno usando o conceito de "teatro performativo" e Hans-Thies Lehmann reconhece os mecanismos de hibridização como um dos traços do que considera um "teatro pós-dramático", que se diversifica à medida que se distancia do drama. Em todas a noções mencionadas, percebe-se a centralidade do conceito de performatividade, que se define em contraposição à representação espetacular. De fato, parece ser esse paradigma, emprestado da performance e de sua ênfase nas ações no presente, supostamente realizadas sem mediações, que talvez possa enfeixar as muitas terminologias que pretendem dar conta dessa cena expandida e híbrida. Não por acaso, todas elas têm como principal universo de análise o teatro das últimas décadas do século XX e a disseminação da arte da performance, que sem dúvida invadiu o campo de criação teatral para transformá-lo radicalmente.

Opondo-se à ênfase na performance, nos estudos iniciais que dedica ao assunto, lleana Diéguez enfrenta a "problemática dos campos expandidos" recorrendo ao conceito de teatralidade, definido, nesse caso, como um dispositivo que atravessa o teatro e o transcende, de modo a deslocar os limites do teatral e do artístico (DIÉGUEZ, 2014, p. 125-129).

O ponto de partida da análise é a discussão aberta pelo teórico de artes plásticas Michael Fried, ao reconhecer a teatralidade como dado emergente na arte minimalista da década de $1960 .{ }^{1}$ Fried foi uma das expressões mais marcantes do pensamento teórico antiteatralista, especialmente representado no livro Absorption and theatricality. Em artigo anterior, Art and objecthood,

1 As concepções de Fried foram desenvolvidas em FRIED (1980 e 1998). Usei também a tradução francesa (FRIED, 2007). 
de 1968, o crítico sustenta que a autonomia das artes plásticas no modernismo findou no momento em que a realização da obra passou a depender da recepção do público, de sua capacidade de transformá-la e completá-la com sua leitura. Para o teórico, o inacabamento das obras minimalistas, afirmado em sua perspectiva relacional, com direção explícita ao espectador, teria correlatos na interação do ator com o espectador. Segundo o crítico, as obras "literalistas" de Robert Morris, Donald Judd, Carl Andre ou Tony Smith estão interessadas nas circunstâncias reais de seu encontro com o espectador e na experiência do "objeto em situação" que, por definição, inclui aquele que vê (FRIED, 1980, 1998, 2007). A literalidade e a afirmação do objeto enquanto mero objeto, expandido em direção ao mundo, evidencia a dependência de seu estatuto artístico à situação em que se coloca, ou seja, à relação entre ele e o observador.

Não é intenção deste texto aprofundar a análise de Fried. O que importa é destacar a oposição do crítico à minimal art pelo fato de ela deslocar-se do lugar autônomo de ocorrência das artes visuais para situar-se entre as artes no caso, entre o teatro, a pintura e a escultura -, questionando as concepções tradicionais de especificidade dos campos artísticos. O fato é que a afirmação de Fried $(1980,1998,2007)$ de que "aquilo que se encontra entre as artes" é o teatro salienta a posição híbrida e liminar das artes da cena que, de fato, situam-se entre as artes e desafiam a separação tradicional entre campos artísticos específicos. ${ }^{2}$ Além do mais, associando essa participação à ideia de teatralidade para remeter à experiência literal do minimalismo, Fried ressalta a condição do objeto em situação, que evidentemente inclui o observador.

\section{Teatros de operação}

O movimento de hibridação das artes e de superação dos limites entre os campos artísticos pode ser considerado um primeiro passo em direção à paulatina perda de autonomia e especificidade da obra artística. De fato, a

2 Aliás, a separação que o crítico referenda foi explicitada, por exemplo, nas sempre mencionadas distinções de Lessing entre as artes do espaço, supostamente sincrônicas, e as artes do tempo, tramadas na diacronia. Ao criticar a arte minimalista por seu caráter teatral e por transformar em experiência de temporalidade o espaço da obra plástica Fried não faz mais que reafirmar a distinção tradicional entre as artes que Lessing sistematizou no século XVIII. 
ampliação do território teatral, definida, em um primeiro momento, como travessia da linha fronteiriça que separa as artes, e que levou à emergência de manifestações como o teatro performativo, a dança-teatro, o cinema expandido, as instalações, as ocorrências site specific e outros modos de situação liminar, tramados na mistura de procedimentos e de linguagens, parece constituir um movimento inicial de expansão, ainda referido à desconstrução da representação.

À medida que se aproxima o século XXI, nota-se, no campo da teoria do teatro, uma evidente necessidade de buscar novos modos de sintonizar-se com as mudanças crescentes no contexto de criação das artes. À nomeação e ao estudo das linguagens miscigenadas, que até então respondiam ao campo expandido das artes, vêm juntar-se um novo paradigma, agora referido à evidente priorização do processo em detrimento do produto teatral acabado, o espetáculo, com consequente valorização da incompletude das manifestações cênicas e do caráter provisório e processual das experiências. Nesse caso, não se trata mais de ressaltar o hibridismo de linguagens, mas da tentativa de subtrair do teatro o caráter espetacular de obra acabada. É uma tendência de subtração de elementos semelhante à que Gilles Deleuze reconhece no teatro de Carmelo Bene (DELEUZE, 2010).

Não se pretende usar os pressupostos de Deleuze em sua inteireza, já que contemplam múltiplas instâncias filosóficas que não é possível enfrentar aqui. O que interessa reter da hermenêutica deleuziana é o movimento que desloca o artista para a função de um operador agindo por subtração, alguém que projeta o teatro na via de uma amputação cirúrgica. Para o filósofo, esse teatro de operação está ligado à supressão daquilo que faz ou representa um sistema de poder. Quando se decide excluir elementos de poder de um texto, por exemplo, não é apenas a matéria teatral que muda, mas o próprio estatuto do teatro, que se afasta da representação e dos mecanismos de poder que ela sustenta. Segundo Deleuze (2010, p. 64), o deslocamento vai liberar novas potencialidades do teatro que, nessa circunstância, torna-se "uma força não representativa sempre em desequilíbrio". De certa forma, a "força não representativa" é o núcleo desse teatro "de menos" a que o filósofo se refere, mas também do teatro expandido que se mencionou há pouco, o que dá a ambos o direito de se opor à fala "maior" do poder. Como nota Deleuze, o teatro surgirá, então, como aquilo que 
opera "alianças aqui ou ali conforme o caso, seguindo linhas de transformação que saltam para fora do teatro" (DELEUZE, 2010, p. 64).

É perceptível que esse teatro de operação está disseminado em diversas vertentes da cena contemporânea e se faz na via de acionamento de diversos dispositivos. O que interessa analisar aqui é a construção de uma teatralidade em que o processo criativo é visível e apresentado ao espectador. Sabe-se que, por muito tempo, e obedecendo às exigências de preservação da ilusão, esse processo construtivo manteve-se parcialmente invisível, ou mesmo escondido, com as instruções e os enunciados inacabados, explicitando-se apenas durante os ensaios. A passagem do teatro da representação para o teatro do processo pressupõe que as soluções provisórias e os experimentos sejam incorporados à apresentação, abrindo espaço para exercícios performativos e amostragens de ensaios, recorrentes em diversas experiências teatrais contemporâneas.

Na maioria das vezes, o espetáculo que os criadores desse teatro apresentam, indica, em suas soluções intencionalmente precárias, uma mudança radical de foco, do produto para o processo criativo, do teatro-espetáculo para performances inacabadas, processuais, que se distanciam das formalizações canonizadas pela tradição crítica para dar vazão a uma teatralidade expandida, extrínseca e híbrida. Trata-se da projeção de uma "estética da imperfeição", que se contrapõe às imagens fechadas e sedutoras, postas em circulação na "sociedade do espetáculo", ou mesmo de um "retorno do rejeitado que não se submete ao beneficiamento da montagem" (BERNARDET, 2003).

São bons exemplos dessa prática os trabalhos recentes do grupo XIX de Teatro, como Intervenção Dalloway. Ou os experimentos da Cia Teatral Ueinzz. Ou as deambulações do coletivo $O$ PovoemPé em suas primeiras criações, como AquiDentro, AquiFora.

Alguns analistas associam a tendência ao paradigma do jogo. É o caso de Christophe Triau, que chama de "ludismo" a amostragem ostensiva do teatro em vias de construção e percebe, na centralidade dos jogos e dos dispositivos, a tentativa de expor os procedimentos de criação à vista do espectador (BIET; TRIAU, 2006). Trata-se de apresentar os atores em sua prática de trabalho e preservar no espetáculo alguma coisa da espontaneidade dos ensaios, do inacabamento dos workshops, das soluções provisórias encontradas durante a pesquisa para a criação. No teatro brasileiro, o movimento 
é visível nos espetáculos de Enrique Díaz, especialmente em trabalhos com o Coletivo Improviso, como Otro e Não olhe agora, ou na desconstrução de clássicos da dramaturgia por Christiane Jatahy, na apresentação/instalação A floresta que anda, ou nas últimas criações de Antonio Araújo com o Teatro da Vertigem, especialmente a performance site specific $A$ última palavra é a penúltima 2.0 .

Nos casos referidos, o que se observa é uma espécie de território móvel, sem margens fixas, em que várias vertentes da arte contemporânea se friccionam, tornando difícil detectar a linhagem a que pertencem. Nessas cenas, as fronteiras fluidas entre processo e produto, ensaio e espetáculo, vida e representação, teatro contextual e teatro do real, performance e situação são difíceis de demarcar. E é exatamente essa fluidez que indica, como nos casos anteriores, a expansão das experiências teatrais para fora de paradigmas definidos e impele o jogo para situações de compartilhamento de processos e interação imediata com o espectador.

Percebe-se, por trás dessas práticas, a tentativa de reafirmar o jogo como uma espécie de "identidade minimalista" do teatro e a reivindicação das constituintes menores de uma singularidade teatral, particularmente a presença não mediada e não diferida do ator, o presente da representação, a copresença e a experiência fugaz da comunidade que se cria entre performers e espectadores, e tem por corolário a aspiração a uma "implicação participativa", mesmo que simbólica ou metafórica (TRIAU, 2009, p. 33-38). A impressão que se tem é que a fuga ao espetáculo é a intenção mais evidente desse teatro do jogo e do processo, que emprega uma série de dispositivos de acionamento de teatralidade e participação do espectador.

Óscar Cornago nota que, nesses trabalhos, os dispositivos artísticos utilizados se apresentam enquanto tais, ou seja, denunciam sua condição de meros dispositivos que revelam seu mecanismo de acionamento. "O que se entrega ao público não é uma representação, mas um jogo para que possa representar-se por meio dele, de forma ao mesmo tempo individual e coletiva" (CORNAGO, 2015, p. 207).

Nesse caso, fazer teatro é propor uma experiência a ser compartilhada em condição de inacabamento, precariedade e imperfeição e, ao mesmo tempo, reivindicá-la enquanto processo para escapar às armadilhas do 
espetáculo e de sua comercialização no mercado da arte. Como observa Triau, procura-se manter o teatro no que ele pode ter de intrinsecamente "bastardo", contra o risco da autossuficiência espetacular (TRIAU, 2009, p. 34).

\section{Arte e contexto}

A rejeição ao espetacular liga-se especialmente à crítica situacionista de Guy Debord, que, já em 1967, analisa a espetacularização da sociedade no capitalismo tardio. Ainda que a crítica não se dirija especificamente ao espetáculo de teatro, mas descreva as relações sociais sob o capitalismo enquanto experiência atomizada e fragmentada, mediada pelas imagens do consumo - para Debord "a separação é o alfa e o ômega do espetáculo" -, qualquer visualidade ou espetacularidade são, a partir daí, consideradas suspeitas (DEBORD, 1997, p. 21). A processualidade, o jogo e a força do acontecimento configurariam, em princípio, modos de oposição ao espetáculo e um desvio radical da "forma mercadoria", com consequente afastamento dos circuitos de arte atrelados ao mercado.

Não apenas o conceito de espetáculo, mas também o de situação, foi emprestado de Guy Debord para ativar movimentos de expansão das práticas artísticas em direção ao contexto em que se inserem. ${ }^{3}$ Muito evidentes, especialmente no início do novo milênio, são mapeadas por Paul Ardenne no livro Uma arte contextual, dedicado à análise de criações em meio urbano em situações de intervenção e participação. Ardenne observa que, nesse período, a arte praticada em espaços convencionais, como galerias, museus - e, pode-se acrescentar, edifícios teatrais -, passa a ser considerada, em sua totalidade, emblemática do poder econômico ou simbólico do capitalismo tardio. Para escapar ao circuito da arte-mercadoria, os criadores optam por desertar dos "perímetros sagrados da mediação artística" para trabalharem na rua ou em espaços públicos que, em princípio, permitem resistir à instituição (ARDENNE, 2004, p. 10).

3 No Relatório sobre a construção de situações e sobre as condições de organização e de ação da tendência situacionista internacional, de 1957, Guy Debord afirma: "Nossa ideia central é a construção de situações, isto é, a construção concreta de ambiências momentâneas da vida em uma qualidade passional superior. [...] Devemos construir ambiências novas que sejam ao mesmo tempo produto e instrumento de novos comportamentos. Para tal convém utilizar empiricamente, no início, as condutas cotidianas e as formas culturais existentes, mas contestando os seus valores" (JACQUES, 2003, p. 53-54). 
Ardenne entende por "arte contextual" o conjunto de formas de expressão cujo ponto comum é a negação das qualidades especificamente "artísticas". Inclui no movimento a arte de intervenção, a arte feita em espaço urbano, as performances de rua, as ações em situação, as experiências site specific, além das criações chamadas participativas ou ativistas. Em todos os casos, trata-se de ações intimamente ligadas ao contexto, ou ao "conjunto de circunstâncias em que um fato se insere" (ARDENNE, 2004, p. 12). Exatamente por isso, são práticas que priorizam a relação direta com a realidade, sem intermediários, em verdadeira inserção no mundo concreto, no universo social, político e econômico, em confronto imediato com as situações materiais em que se produzem. $O$ autor afirma que, por serem realizadas em "contexto real" e renegando qualquer procedimento que se ligue à autonomia artística, podem ser consideradas herdeiras legítimas do realismo de Courbet, já que pretendem religar-se a situações cotidianas e produzir-se em relação estreita com o contexto (ARDENNE, 2004).

Sem discutir o exagero da comparação, é inegável que a importância dada ao contexto é um dos principais motores do deslocamento das atividades artísticas por meio de uma "pulsão participativa e agorética", feita de engajamentos pontuais, políticos ou éticos, e de uma atenção permanente à atualidade e à necessidade de refletir sobre as condições sociopolíticas de emergência da arte e, por extensão, do papel do artista em relação ao poder e às instituições. A materialização das proposições em determinado contexto tem caráter experimental e processual, pois trata-se de acionar mecanismos simbólicos a partir de situações singulares e específicas. É evidente que um trabalho criado a partir da relação com o entorno depende do modo como se articula o "mundo real em movimento", de natureza processual semelhante à dos projetos que se apresentam. Segundo Ardenne, a conexão imperativa com o contexto e a recusa da autonomia artística são frutos de um posicionamento mais político que estético, regido por princípios de colaboração que reivindicam, em primeiro lugar, a relação com o outro (ARDENNE, 2004).

\section{Relação e comunidade}

É nesse sentido que a arte contextual se aproxima, em vários aspectos, das microcomunidades participativas e relacionais que se organizam a 
partir de princípios analisados por Nicolas Bourriaud. De fato, também para Bourriaud (2009), o grau máximo da separação que afeta o domínio das relações humanas é a reificação, que substitui os vínculos sociais por mercadorias e os transforma em produtos padronizados. Na visão do autor, a separação que atinge o cerne das relações é a última etapa de transformação da "sociedade do espetáculo" descrita por Debord. No hipercapitalismo, até mesmo os vínculos sociais não são diretamente vividos, mas mediados pelo espetacular. O esboço de "utopias da proximidade" é a tentativa de escapar, ao menos parcialmente, à uniformização dos comportamentos, por meio de práticas artísticas que se envolvem no território da experimentação social.

É dessa forma que se explicam os pressupostos de Borriaud (2009), para quem a arte contemporânea não projeta realidades imaginárias ou utópicas, mas propõe modelos perceptivos, experimentais, críticos e participativos com potência suficiente para constituir modos de existência e de ação. Portanto, mais que afirmar um espaço estético e simbólico autônomo, a arte relacional visa à esfera das interações humanas em contexto social. Seu substrato é o campo da intersubjetividade e seu tema é o "estar juntos". "A arte é o lugar de produção de uma socialidade específica", observa o crítico (BORRIAUD, 2009, p. 16-41), centrada na produção de "modos de convívio" e na criação de "microcomunidades" ou "coletividades instantâneas" regidas por princípios singulares. Exatamente por isso, no contexto relacional a "coisa artística" não é efeito de uma composição específica, mas a ativação de uma trajetória que se desenrola por meio de "formações" parciais, não fixas, que só existem na relação dinâmica com outras formações, artísticas ou não. E Bourriaud completa: "cremos ser possível explicar a especificidade da arte atual com o auxílio da ideia de produção de relações externas ao campo da arte [...]: relações entre indivíduos ou grupos, entre o artista e o mundo e, por transitividade, relações entre o espectador e o mundo" (2009, p. 37).

Diante do exposto, fica evidente que a produção relacional implica uma expansão quase ilimitada dos domínios da arte, pois as próprias relações humanas são consideradas artísticas e podem incluir reuniões, ocupações, encontros, manifestações, jogos, locais de convívio e modos de colaboração entre as pessoas. Em resumo, segundo Bourriaud (2009), diversas formas de contato e invenção de relações representam, hoje, objetos estéticos passíveis 
de análise. A prática da arte é a criação de experiências e possibilidades de vida em determinados contextos, na via de contratos estéticos que pouco se distinguem dos contatos sociais.

\section{giro social da arte}

A retomada do ativismo nas instâncias da arte contextual e relacional desenvolve-se de modo paralelo à explosão dos movimentos de minorias, o que sem dúvida contribui para levar as artes a uma aproximação mais incisiva com a política. É o que Claire Bishop (2012a) considera um "giro social" da arte, que localiza no final do século $X X$ e que, sintomaticamente, parece deixar para trás o "giro performativo" detectado por Fischer-Lichte em décadas anteriores do mesmo século. Para Bishop, a postura social característica de vários criadores é especialmente visível na rejeição à estética e à formalização, substituídas por intervenções decididamente ligadas ao trabalho em comunidades e à atuação em frentes próximas do trabalho social. Como nota a ensaísta, ainda que prefiram ser avaliadas no campo da arte, essas práticas têm muito mais proximidade com ações sociais, já que é difícil distinguir nelas algum tipo de especificidade artística. Os experimentos são valorizados por sua inserção em contextos e situações específicos, de preferência conflagrados, e a potência de intervenção na realidade é, sem dúvida, mais importante que qualquer tipo de formalização estética.

Nas análises que faz sobre a arte de participação em seu livro, Artificial hells, Bishop liga a teorização produzida sobre a prática artística participativa ao situacionismo de Guy Debord, que também se empenha em interferir na realidade na tentativa de reparar vínculos sociais rompidos. A autora nota que as práticas participativas são descentradas e heterogêneas e, na tentativa de abrir canais para uma mudança social, sustentam-se na criação de redes de colaboração. Por isso, os projetos priorizam a construção de situações antimercadológicas e politicamente engajadas, materializadas como importantes gestos de resistência (BISHOP, 2012a).

Bishop faz uma série de ressalvas a essas práticas artísticas, afirmando que é necessário começar a discuti-las e analisá-las criticamente também "como arte", mesmo quando a categoria permanece ausente dos projetos, 
essencialmente antropológicos e sociológicos. Segundo a ensaísta, o deslocamento da estética do centro dos debates deve-se à compreensão de que ela serviria para mascarar desigualdades, opressões e exclusões de raça, gênero e classe. No trajeto dessa desvalorização, os principais inimigos são o formalismo, a descontextualização e a despolitização, considerados sinônimos de mercado e conservadorismo cultural (BISHOP, 2012a, p. 18). ${ }^{4}$

$\mathrm{Na}$ tentativa de reabilitar a ideia de estética em conexão com a política, Bishop recorre ao filósofo Jacques Rancière e suas concepções de "partilha do sensível" e "regime estético da arte." Para a ensaísta, esses pressupostos têm a vantagem de dissolver as visões binárias que, em geral, frequentam o discurso politizado da arte de participação, e costumam opor individual e coletivo, autor e espectador, ativo e passivo, arte e contexto, estética e política. Concordando com Rancière, acredita que o risco dessas polarizações é o foco exclusivo na suposta "eficácia real" das práticas artísticas.

De fato, Jacques Rancière é bastante cético a respeito do que chama de "giro ético" da estética e da política, que constata em segmentos da arte do século XXI. Quando menciona o ético, não se refere ao julgamento moral sobre as operações da arte e as ações da política, mas à constituição de uma esfera indistinta de "imediatez ética" onde se dissolvem as especificidades das práticas artísticas e políticas. Trata-se de um

modelo de arte que deve suprimir-se a si mesma, de teatro que deve inverter sua lógica, transformando o espectador em ator, da performance artística que faz a arte sair do museu para fazer dela um gesto na rua, ou anula dentro do próprio museu a separação entre arte e vida. (RANCIÈRE, 2012, p. 56)

Rancière chama de consenso a supressão dessa divisão e a consequente constituição de um modo de estruturação simbólica que esvazia o dissenso, núcleo da política. Para o filósofo, a desaparição das diferenças entre política e estética na indistinção ética é característica de um contexto em que a visão da arte está atada ao vínculo social e se exprime, por exemplo, no

4 Em Bishop (2012a), um dos principais objetivos da análise é enfatizar a estética no sentido de aisthesis, um regime autônomo de experiência que resgata para ampliar o debate que depreende o valor artístico dos projetos de participação recorrendo a critérios éticos. Ver, a respeito, outro ensaio da autora (2012b). 
programa da arte relacional, cuja intenção é criar situações de proximidade propícias à elaboração de novos modos de ligação social. ${ }^{5}$ Por meio desse mecanismo de deslocamento, os dispositivos artísticos, antes polêmicos e dissensuais, tendem a restringir-se à função social, transformando-se em testemunhas ou símbolos da participação de uma comunidade indistinta, ativada na perspectiva de restauração de um mundo comum (RANCIÈRE, 2004, p. 145-173). Rancière argumenta que o regime estético da arte é constitutivamente contraditório e necessita de um objeto ou de um espetáculo que faça a mediação entre a ideia do artista e a interpretação do espectador. Trata-se da "terceira coisa" a que os dois lados podem se referir, aquilo que os une e ao mesmo tempo os separa. Também por isso, a eficácia da estética não é a relação de causa e efeito entre as intenções do artista e a recepção do espectador. Trata-se, ao contrário, de uma eficácia paradoxal, ligada à separação entre as formas sensíveis da produção artística e as formas sensíveis de recepção. "A eficácia estética é a eficácia de uma distância”, conclui Rancière (2012, p. 56), para quem a arte e o social não devem ser reconciliados, mas manter-se em contínua tensão.

De certa forma, um deslocamento semelhante é visível na alteração dos pressupostos de análise do teatro contemporâneo, especialmente realizada por teóricos alemães. É o caso de André Eiermann e o conceito de teatro "pós-espetacular", também utilizado por Helga Finter, que destaca a emergência de formas de crítica ao espetacular diferentes daquelas propostas por Debord. De acordo com o ensaísta, na atual "sociedade do hiperespetáculo", as utopias de autenticidade social, que demandavam o não-mediado da presença, do "relacional" e da "imediatez" no contexto artístico, foram há muito capturadas pelo próprio espetáculo. Eiermann percebe uma reação a essa captura em alguns trabalhos de teatro das primeiras décadas do século XXI, com a criação de modos cênicos que tentam expor novamente as divisões. $\mathrm{Na}$ relação entre atores e espectadores, por exemplo, percebe que a ordem simbólica volta a intervir como um terceiro que "questiona a representação da

5 É conhecida a polêmica de Jacques Rancière e Claire Bishop com a estética relacional de Nicolas Bourriaud. As restrições de Rancière aparecem, por exemplo, em RANCIÈRE (2012). A resposta de Nicolas Borriaud está no artigo Precarious constructions: answer to Jacques Rancière on art and politics e no livro Radicante (2011). 
comunidade imediata encarnada na imagem da comunicação cara a cara". E acrescenta que, em geral, as formas de teatro pós-espetacular se contrapõem à imediaticidade dessa relação, pois estão interessadas na reflexão crítica sobre ela, manifestando, às vezes até literalmente, um mediador ativo entre cena e público. Segundo Eiermann, ele permite a interação entre atores e espectadores precisamente via mediação, ou seja, por meio da interrupção da interação, que abre a possibilidade de percepção mútua das duas instâncias (EIERMANN, 2012, p. 1-24).

\section{O trabalho de Lia Rodrigues}

O trabalho de Lia Rodrigues e sua companhia, sem dúvida, pode ser considerado um modo de teatro expandido que consegue operar uma associação singular das tendências referidas. As criações da coreógrafa e de seu coletivo são marcadas, desde o princípio, pelo contexto social brasileiro em que se inserem, especialmente, a partir da mudança para a comunidade da Maré, no Rio de Janeiro, em 2004. Isso acentua a potência política das experimentações, sem deixar de manter uma autonomia artística que talvez se possa chamar de dissidente, por deglutir modos performativos, coreográficos e teatrais na via de um ativismo artístico inédito em suas práticas contextuais e relacionais e também nas conformações estéticas. Arte contextual, relacional, de participação, performativa, teatral e dançarina, o trabalho de Lia talvez constitua algo aproximado do que Rancière chama de dissenso, à medida que consegue manter a tensão instável entre estética e política.

Desde a fundação da Lia Rodrigues Companhia de Danças, em 1990, as criações se definiram por uma ação sem fronteiras, em que dança, teatro e artes plásticas se contaminaram de ativismo político para impulsionar uma expansão incontrolável do campo da arte em direção ao contexto brasileiro. No início da trajetória já é visível a opção pelo diálogo íntimo com as situações públicas, na projeção de um modo novo de configuração do político na arte, ligado à forma de fazê-la, organizá-la e produzi-la e aos dispositivos usados para "provocar pensamento", pressupostos fundamentais de uma arte política.

Os longos processos de criação da companhia, à semelhança de grupos de teatro brasileiros como o Vertigem e o XIX, podem ser considerados 
colaborativos. As aprofundadas pesquisas teóricas que os subsidiam resultam em trabalhos dificilmente identificáveis apenas como dança, com espectadores e bailarinos dividindo o mesmo espaço, economia máxima de recursos cênicos, ausência de música ou "trilha sonora", luz aberta clareando as dilatações temporais, as pausas e os silêncios, corpos nus em posturas estranhadas que os desfiguram e insinuam inscrições da história e informações do ambiente, literalmente incorporando o estado social e cultural de determinados contextos do país (LIMA, 2007, p. 75-76).

A posição da artista contra a cultura de mercado e o enfrentamento, a seu modo, da crise generalizada da representação estética, social e política no contexto brasileiro conflagrado de desigualdade, opressão, assassinatos em série de lideranças comunitárias, indígenas, negros, sem-terra e sem-teto são determinantes da opção pela residência na Maré, um dos maiores complexos de favelas do Rio de Janeiro.

No conjunto de dezesseis comunidades que compõem a Maré habitam cerca de cento e quarenta mil pessoas, distribuídas no trecho que se estende ao longo da Avenida Brasil, do bairro de Ramos ao Caju. A construção da extensa via de circulação que une o centro às áreas periféricas da zona oeste da cidade, iniciada em 1939 e só concluída em 1946, foi um dos fatores determinantes para o surgimento da favela. Como aconteceu na construção de Brasília e em tantas outras cidades brasileiras, os operários que trabalharam na obra foram obrigados a se fixar em lugares precários em seus arredores, pois não tinham condições econômicas de morar em bairros urbanos já estabelecidos.

Passados alguns anos de mudança para a comunidade, Lia Rodrigues e sua companhia conseguiram construir um galpão de mais de mil metros quadrados para funcionar como sede de trabalho, o Centro de Artes da Maré, inaugurado em 2009. A partir dessa data, os espetáculos criados estreiam nesse espaço, que também é usado como centro de formação, difusão e desenvolvimento de projetos artísticos. Nessa altura, fica cada vez mais evidente para Lia que, no contexto em que se situa, o ato de criar não pode se restringir à produção de uma obra. Além da criação artística, é preciso buscar modos diferentes de intervir, subsistir e abrir espaços onde seja possível compartilhar. Dessa necessidade, surgem os três principais eixos de ação 
da companhia: a construção do centro de artes para abrigar as próprias atividades e as criações de outros artistas, a formação continuada por meio de aulas, ensaios e discussões, e a pesquisa e o trabalho artístico de criação (SOTER, 2010, p. 147). A ampliação da proposta se faz com a abertura, em 2011, da Escola Livre de Dança da Maré, destinada a moradores da região, que hoje conta com uma média de trezentos alunos, divididos em oficinas gratuitas de diferentes linguagens de dança e trabalhos de corpo.

Tanto o centro de artes quanto a escola de dança são fruto de parceria da companhia com a Redes de Desenvolvimento da Maré, organização não governamental que reúne moradores e ex-moradores da favela. Em entrevista recente, Lia relata como descobriu um modo de trabalhar na comunidade, o qual considera um "exercício diário de diferenças". "Hoje a Maré está impregnada em mim. [...] O lugar onde estamos está inscrito no nosso corpo e na maneira de nos movermos. Acho que essa ideia de encontro das diferenças, de mistura e de invasão vem mesmo permeando meu trabalho nos últimos anos", continua a artista, afirmando que a residência na Maré traz para a companhia a necessidade de "outrar", não para se transformar totalmente no outro, mas para se colocar em um lugar que permita enxergar melhor a diferença, para "estar junto mesmo sem combinar" (RODRIGUES apud PAVLOVA, 2017).

Eliana Sousa Silva, diretora da Redes da Maré, ressalta outros aspectos da parceria:

Lia trouxe para a Maré a possibilidade de encontro entre diferentes experiências de cidade. [...] Nossa parceria ajudou a estruturar de forma mais organizada um pensamento sobre arte e cultura que vai além do acesso. Ajudou a organizar o nosso pensamento para materializar os desejos de ter de fato um espaço legítimo para a arte na Maré, que dialoga com a ideia de superar as representações da favela. (SILVA apud PAVLOVA, 2017) ${ }^{6}$

Lia concorda com Eliana quando lembra que a intenção de criar o projeto na Maré veio da necessidade de inventar alguma coisa que ainda não existia e, principalmente, de experimentar de que forma um "projeto de arte

6 As citações foram retiradas de entrevistas de Lia Rodrigues e Eliana Sousa Silva a Adriana Pavlova, reproduzidas na reportagem PAVLOVA (2017). 
contemporânea dialoga com um projeto social". O questionamento desencadeia uma reflexão incessante sobre o diálogo entre dança contemporânea e contexto da favela, que vai sendo experimentado a cada nova criação (BIEDERMAN, 2017).

Uma das respostas já é visível no primeiro espetáculo estreado depois da mudança para a Maré, Encarnado, de 2005. Quando a companhia iniciou a residência na favela, em 2004, ele já estava em pleno processo de criação, com as primeiras células coreográficas concebidas em uma sala de ensaios no porão do Teatro Villa-Lobos, em Copacabana. O espetáculo sinaliza um mergulho no contexto de diferenças a que Lia se refere, já que a maioria dos dançarinos vêm da zona sul do Rio de Janeiro e compartilha uma formação em dança e teatro construída durante anos de estudo e criação conjunta. Para a dançarina Amália Lima, que está no grupo desde 2000, e atualmente é assistente de direção de Lia Rodrigues, na chegada à Maré os bailarinos se sentiram extremamente vulneráveis ao mundo desconhecido da comunidade, em que os ensaios eram feitos em meio a ruídos de tiros e voos rasantes de helicópteros da polícia militar.

A gente era muito ignorante, não conhecia nada sobre o lugar ou mesmo sobre a ONG que era nossa parceira. O que eu lembro daquela época era a gente correndo para se esconder quando escutava um monte de helicóptero voando no céu. Foi um processo muito doido, cheio de fantasmas nos rondando, fantasmas que estavam ligados também às leituras do livro da Susan Sontag [Diante da dor dos outros]. Havia uma ligação clara com o que estávamos vivendo, que era não estar dentro da tragédia propriamente dita, mas, ao mesmo tempo, pensar como ser solidário à tragédia. (LIMA apud PAVLOVA, 2015) ${ }^{7}$

Eliana Sousa Silva (2012), que chegou à favela de Nova Holanda aos 7 anos e ali residiu até os 28 , relata a brutalidade policial institucionalizada nas comunidades pobres do Rio de Janeiro (mas não apenas ali) e os conflitos com grupos armados que se organizam em torno do tráfico. Para a diretora da Redes de Desenvolvimento da Maré,

7 A entrevista de Amália Lima concedida a Adriana Pavlova está incluída no texto Encarnado: uma leitura coreopolítica do projeto de Lia Rodrigues na Favela da Maré, publicado em 2015 na revista Dança. 
os enfrentamentos entre os grupos de jovens dedicados ao tráfico de drogas e os policiais eram comuns no cotidiano e, por essa razão, havia necessidade permanente de negociar com ambos os grupos, com a ideia de evitar conflitos que expusessem os moradores a fim de coibir ações arbitrárias, em especial por parte das forças policiais. Em função disso, evidenciou-se para mim não ser mais possível considerar a melhoria de qualidade de vida dos moradores das favelas sem buscar construir novos olhares e proposições sobre o fenômeno da violência, que se tornou principal problema dos centros urbanos brasileiros, desde o final do século $\mathrm{XX}$, em particular para os moradores dos territórios favelados. (SILVA, 2012, p. 61, p. 35-36)

Após a mudança da companhia para a Maré, dois dançarinos moradores foram incorporados a Encarnado. Allyson Amaral e Leonardo Nunes, à época estagiário da companhia, envolveram-se na concepção do trabalho a ponto de interferir na construção de cenas, levando ao grupo experiências sobre o dia a dia da comunidade. O olhar agudo para a violência cotidiana e os assassinatos recorrentes diferenciava os moradores da favela dos dançarinos da Zona Sul.

O olhar do Leozinho [Leonardo Nunes] foi fundamental. Ele dizia que a gente que era de fora da favela morria muito bonito, arrumado, esticadinho, e que o povo da Maré não morria daquele jeito, não. Foi ele que mostrou que se morre todo quebrado, com os pés para um lado e as mãos para o outro, como acabamos fazendo em cena. (PAVLOVA, 2015)

A despeito da indicação mimética, a violência não estava presente em Encarnado apenas como emulação da morte desmembrada. Os corpos nus labuzados de sangue falso, feito de ketchup, os vômitos e defecações, também tingidos de vermelho, os gritos e os respingos rubros nas camisas brancas, como buracos de bala, os bailarinos-cães que se movimentavam de quatro e atacavam uma bailarina com violência, arrastando-a pelo chão e arrancando com fúria trapos de estopa que simulavam vísceras, eram figuras extremas, mas formalmente elaboradas, que sem dúvida surgiam da contaminação dos corpos dançarinos com o novo contexto de trabalho. $O$ que se percebia é que esses corpos treinados, moldados por longa prática de dança contemporânea, ofereciam uma espécie de resistência estética à violência do entorno e o resultado era um encontro dissonante, tensionado entre arte e contexto. 
Em excelente análise de Encarnado, Adriana Pavlova associa a dança de Lia Rodrigues ao conceito de coreopolítica explorado por André Lepecki (PAVLOVA, 2015). O ensaísta associa o termo a múltiplas formações do que considera a coreografia hoje, e que se expandem muito além do campo restrito da dança. Segundo Lepecki (2012, p. 47), trata-se de um modo de atuação que se aproxima do que Paul Carter chama de "política do chão," e que implica uma atenção específica a todos os elementos de uma situação para perceber como suas particularidades físicas formam "um plano de composição entre corpo e chão que se chama história". Uma política coreográfica do chão seria a emergência dos muitos modos como a dança finca seus pés nos contextos específicos que a sustentam e, em contrapartida, como os diferentes "chãos" sustentam diferentes danças e as transformam, à medida que são transformados por elas. Para entender melhor essa interação constitutiva, uma espécie de "dialética infinita" tramada entre "as danças e seus lugares e entre os lugares e suas danças", Lepecki recorre a Carter para afirmar que elas evitam "o achatamento filosófico e topográfico do chão rugoso" em uma superfície "linear e sem rachaduras". A coreopolítica faz que o chão se mova e trema, "sacudindo os caídos" e fazendo aflorar as "cicatrizes de historicidade", que o recortam e fendem. Como acontece em Encarnado que, no tropeço, ensaia um sujeito político capaz de exercitar sua potência para o dissenso. Nesse caso, a rachadura "não é mais do que chão emergindo como força coreopolítica: desequilibrando e desestabilizando subjetividades predeterminadas e corpos pré-coreografados" (LEPECKI, 2012, p. 57). ${ }^{8}$

Pororoca, de 2009, Piracema, de 2011 e Pindorama, de 2013, que Lia Rodrigues considera uma trilogia de águas e coletividades, foram espetáculos totalmente criados no Centro de Artes da Maré, no percurso de aproximação e confronto dos "corpos pré-coreografados" com a favela, os moradores e o contexto.

A primeira criação foi Pororoca, que empresta o título da expressão indígena que significa "estrondar" e se refere ao fenômeno natural de encontro das águas do mar com a foz do rio Amazonas. A confrontação entre correntes opostas remete à dificuldade de convivência e ao choque de diferenças nos primeiros tempos da Maré e, em cena, os fluxos de bailarinos experimentam

8 Lepecki se reporta a Carter (1996). 
coreograficamente as dificuldades que marcam o início da residência. Piracema é o trabalho seguinte, que também empresta o termo dos indígenas brasileiros e indica a viagem dos cardumes nos rios da Amazônia até o local de desova. É uma investigação, via corporeidade, dos modos de convívio e das maneiras de se relacionar com o entorno e lidar com a alteridade.

Pindorama, que estreia dois anos depois, inspira-se na palavra de origem tupi com que os indígenas nomeavam o Brasil antes do descobrimento - "terra das palmeiras." Encerrando a trilogia, é uma figuração distorcida das tentativas de sobrevivência em contexto conflagrado. O núcleo central da cena é uma dançarina que tenta se equilibrar em meio a uma enorme tira de plástico sacudida pelos integrantes da companhia. Ou uma mulher nua que se debate na tentativa de salvar-se das águas agitadas por ondas cada vez mais violentas, que a impedem de controlar os movimentos. Muito próximos da performance, dividindo o mesmo espaço com os bailarinos, os espectadores são parcialmente envolvidos na agitação incessante.

Em crítica do espetáculo, Christine Greiner observa que "o modo como esta experiência rompe a dicotomia entre quem faz e quem assiste" não é o habitual. De fato, trata-se de um mergulho do espectador na experiência de torvelinho, não porque seja convidado a participar da cena, mas porque é engolfado na energia que esborrifa da intensidade dos movimentos em expansão no espaço, e que circula entre todos. Sem dúvida, é uma comunidade provisória que se forma, mas feita de dissidências, pois a tensão entre bailarinos e espectadores, artistas e público mantém-se como um confronto político de lugares e posições. A diferença é visível, por exemplo, na qualidade dos movimentos de Amália Lima, em agitação equilibrada em cima da maré de plástico, ou na ação exímia dos bailarinos que Ihe dão vida, numa coreografia milimetricamente executada. ${ }^{9}$

9 Na crítica referida, Vidas exauridas e o céu que está prestes a despencar, Christine Greiner menciona "a qualidade dos movimentos dela [Amalia Lima] mas também de quem dá vida ao oceano". E continua: "O plástico-cenário é usado também na segunda parte, de novo com a mesma maestria. Saem as águas, agora é a luta literal pela sobrevivência quando o chão não cabe nos pés. Cinco corpos de bailarinos nus se encontram e se repelem no meio de um furacão". É sintomático que a estreia de Pindorama tenha acontecido quando o exército brasileiro ocupava a Maré, em 2014. Nova intervenção militar na Secretaria de Segurança Pública do Rio de Janeiro foi decretada no momento em que escrevo este texto, março de 2018. 
É possível recorrer ao crítico de dança Gerald Siegmund para pensar a comunidade dissonante proposta, não apenas nessa cena, mas no trabalho de outros coletivos fundados na concepção da estética como esfera de reflexividade das práticas sociais, que preservam um modo estético de separação do contexto de onde provém. Nesse sentido, as produções não são modelares, mas mantém-se enquanto percursos singulares de questionamento, sugerindo comunidades provisórias, por natureza despedaçadas (SIEGMUND, 2003, p. 334).

De fato, a conformação espacial de Pindorama solicitava uma movimentação incessante de bailarinos e espectadores dividindo o mesmo espaço, o que vai se repetir nos trabalhos seguintes da companhia. Nesse caso, especialmente na segunda parte da apresentação, os bailarinos surgiam com dezenas de balões cheios de água e os espalhavam no chão de cimento. O movimento lento e cuidadoso de distribuição obrigava os espectadores, muito próximos, a se reposicionarem para dar espaço à nova situação. Mas a parada nunca se mantinha e, pouco depois, tinham que se deslocar à procura de outros lugares, pois os performers instalavam novas bolsas de água por todos os lados. Depois da distribuição, deitavam-se sobre elas e começavam a rastejar por todos os lados espatifando-as e "desafiando os pés e os corpos" de quem estava em volta. Nessa altura, no chão quase aquático, "corpos estrebucham, respirando afanosamente, numa proximidade do público que desconcerta, deixando a plateia em estado de prontidão".

\section{Como segurar o céu?}

O que cada um de nós pode fazer para segurar o céu e interromper o processo de destruição do planeta é a principal pergunta que Lia Rodrigues fez a seus bailarinos no início da criação de Para que o céu não caia, estreado em 2016. Como sempre acontece nos trabalhos da coreógrafa, os mais de nove meses de processo começaram com questionamentos dirigidos não apenas aos membros da companhia, mas organizados em um longo "questionário afetivo-cultural-corporal," concebido como uma das ações do programa Dançando com a Maré. Os bailarinos da companhia, dezoito jovens do Núcleo 2 da Escola Livre de Danças da Maré e duas estagiárias, percorreram as ruas para 
pedir que as pessoas respondessem a perguntas formuladas coletivamente, relacionadas ao corpo, ao que era a dança, à vida na favela, àquilo de que mais gostavam, à relação com o outro e ao próprio Centro de Artes. Foram mais de duzentas perguntas respondidas por mais de duzentos entrevistados.

A partir da experiência de cartografia do contexto, Lia Rodrigues pediu a bailarinos e estudantes que criassem uma "resposta estética" ao questionário, transformando as falas dos moradores em exercício coreográfico, o que funcionou como ponto de partida para o espetáculo. ${ }^{10} \mathrm{O}$ testemunho das pessoas sobre suas vidas, seus gestos de trabalho, suas utopias e as violências que sofrem foram modos de ativar a relação entre a arte e os processos sociais, feita em um contexto no qual é inevitável o questionamento sobre a situação do país e de grande parcela da população brasileira.

A esse testemunho da exclusão, a coreógrafa acrescenta outro, de igual ou maior potência. Trata-se do livro do xamã yanomami Davi Kopenawa, que narra o mito do fim do mundo. A queda do céu foi escrito a partir de conversa com o antropólogo Bruce Albert e é o primeiro relato a apresentar a voz da tribo que habita o maior território indígena coberto por floresta em todo o mundo, situado no norte do Brasil e no sul da Venezuela. Verdadeiro manifesto xamânico contra a destruição da floresta amazônica, aborda as questões climáticas e a devastação da natureza a partir de um ponto de vista completamente distinto, ligado à cosmogonia indígena. Se a natureza continuar a ser desrespeitada e não cessar o extermínio da floresta e dos animais, a ruptura da harmonia na Terra fará desabar o céu - "aquilo que está acima de nós" sobre todos os que estão embaixo, incluindo o branco "povo da mercadoria", os índios, as árvores, as plantas e os animais (KOPENAWA; ALBERT, 2010).

Recorrendo aos fundamentos da cultura yanomami, a narrativa de Kopenawa fala de uma terra ainda habitada por xapiris, espíritos que protegem a vida humana e sustentam o céu com sua dança, com capacidade de afastar os seres maléficos e as epidemias dos brancos, mantendo o céu no lugar. Até que o extermínio da floresta e dos últimos povos indígenas provoque sua fuga e o abandono do mundo. "Duplos invisíveis da floresta", esses transmissores do "recado cifrado da mata" são protagonistas de um relato que também

10 Dalen Jacomino (2017) relata o processo. Há também a matéria do jornalista Gonçalo Frota (2017). 
engloba a vida de Kopenawa e sua luta pela demarcação das terras indígenas contra a invasão de garimpeiros, pecuaristas e empresários do agronegócio. Em prefácio ao livro, o antropólogo Eduardo Viveiros de Castro (2010, p. 15) nota que a lucidez política e poética do xamã projeta um "discurso sobre o lugar, porque seu enunciador sabe qual é, onde é, o que é o seu lugar."11

Em certo sentido, o gesto de Lia Rodrigues é uma extensão desse discurso sobre o lugar, feito a partir do próprio lugar. No contexto brasileiro, em que o genocídio das populações indígenas e o extermínio das lideranças comunitárias é cada vez mais frequente, a companhia encontra um modo de unir favela e floresta para resistir à queda do céu. Como Lia explicita na sinopse do espetáculo (2016), "os bailarinos dançam na Maré, no ritmo de máquinas e carros, helicópteros, sirenes, sob um calor escaldante, com chuva e tempestade, [...] para mover o ar e para se expandir. [...] Para que o céu não caia... dançam".

De fato, o complexo de narrativas, imagens, lembranças e símbolos que compõem o livro de Davi Kopenawa é reativado nos corpos da companhia. Como nota Beth Néspoli, alguns dos ritos narrados em $A$ queda do céu são transpostos e reconfigurados no espetáculo, como soprar pó sobre o rosto, ser alvo do olhar fixo de um xapiri ou retorcer o corpo no sono (NÉSPOLI, 2017). Mas o traço mais evidente é a dissociação entre ritual comunitário e estranhamento coreográfico que atravessa o trabalho.

A primeira impressão do espectador ao participar de Para que o céu não caia é que a força da apresentação vem de um coletivo não homogêneo, dissonante e plural. Mesmo nas coreografias feitas em uníssono, os movimentos têm execução distinta, o que abre clareiras para que as singularidades se exprimam não apenas nos raros solos, mas na diferença de corpos, tamanhos, cor, tipo físico, gestualidade e modos de fazer. Sem dúvida, os corpos distintos em alto grau projetam em cena uma "mecânica de diferenças", mas não apenas isso. ${ }^{12}$

11 Além do livro de Kopenawa, a companhia Lia Rodrigues fez a leitura de uma coletânea de ensaios organizada por Viveiros de Castro e Débora Danowski, Há mundo por vir?, em que os antropólogos coligem narrativas populares e científicas que versam sobre o fim do mundo. O livro foi publicado em Desterro (Florianópolis), pelo Instituto SocioAmbiental, em 2014.

12 A crítica francesa Véronique Giraud (2016) usa a expressão para referir-se à diversidade dos bailarinos. 
Muitas sensações são ativadas desde o início, com o aroma intenso de café. O galpão limitado por luz baixa coloca no mesmo nível espectadores e bailarinos, que transitam com potes de pó de café, alinham-se em uma das laterais e, com as mãos cheias do pó, começam a soprá-lo sobre os próprios rostos e corpos, recobrindo a nudez com uma espécie de máscara escura. Mascaramento, pintura indígena, pó de yãkoana colaboram no movimento de "outrar" que reveste os corpos nus de uma segunda pele, operando uma espécie de metamorfose que os aproxima de formas animais ou "criaturas da floresta". A transmutação se repete outras vezes, quando os bailarinos espalham farinha branca sobre o corpo e, no final, pó de açafrão. O resultado é uma pele rugosa, feita de camadas, que parecem justapor realidades e tempos distintos no mesmo corpo. O sopro do pó não envolve apenas os bailarinos, mas o entorno, como se uma nuvem inesperada de poeira cobrisse a cena e remetesse, ao mesmo tempo, a rituais indígenas e à poluição urbana. Pó e poluentes se apresentam juntos.

É visível que a transformação dos bailarinos não se liga a nenhuma tentativa de figurar, de modo mais ou menos realista, o universo ameríndio. Não há intenção de mimetizar animais e índios ou traduzir cenicamente o imaginário de Kopenawa. Nem mesmo quando batem firmemente os pés no chão e alinham os corpos em movimentos circulares, semelhantes às danças em terreiros de aldeia. As passadas fortes, ritmadas, lembram a cerimônia do Kuarup, ritual de homenagem aos mortos, celebrado pelos povos indígenas do Xingu. ${ }^{13} \mathrm{~A}$ intensidade corporal e motora dos performers ao baterem com força os pés no mesmo chão que o espectador pisa, e que treme com a pulsação coletiva, faz circular uma corrente intensa de energia que coloca quem faz e quem vê em situação semelhante. A vibração comum faz lembrar a noção de "energeia" referida pelo crítico André Lepecki, por abrir um campo "afetivo-energético" necessário para a atualização de qualquer movimento engajado em uma situação política específica (LEPECKI, 2013, p. 31).

13 De fato, no processo de criação, os bailarinos trabalharam danças indígenas brasileiras de modo livre, apropriando-se, inclusive, do emblemático Kuarup. Lia fala de "deglutição" e "antropofagia" quando se refere à ativação desses rituais. "Essas danças, tradicionais e indígenas não estão paradas no tempo. Temos milhares, todas diferentes, presentes no nosso quotidiano, na nossa favela, nos nossos corpos. Ativamo-las quando desejamos. Estão ali para serem devoradas, apropriadas, para construirmos o nosso discurso" (RODRIGUES, apud GALHÓS, 2017). 
A situação é interrompida logo em seguida, quando os bailarinos jogam braços e quadris em movimentos rápidos e precisos, saltam, caem, fazem rodopios de torso e braços, que remetem ao vocabulário da dança contemporânea. Trata-se de uma mistura impura de rito e coreografia.

Sem dúvida, essa coreografia se conecta à linguagem experimental das vanguardas da dança contemporânea. Nesse sentido, o posicionamento político do espetáculo é tão definidor quanto a linguagem corporal elaborada, precisa, em que são notáveis as operações de fragmentação, deslocamento e espelhamento das formas do corpo, e a desconstrução e reconstrução contínuas das figuras, rearticulando partes do corpo em um jogo de montagem e decomposição. Da mesma forma que no mascaramento com café, farinha e açafrão, as alterações, deformações e fragmentações visuais, que às vezes se aproximam do monstruoso, criam uma espécie de "membrana" que reveste o corpo e atua como um mediador ativo destinado a desmascarar a imagem corporal e o rosto supostamente imediato do outro (EIERMANN, 2012, p. 19). ${ }^{14}$

É interessante perceber como, em grande parte do espetáculo, os movimentos dos bailarinos se orientam para o chão, ou se fazem em expansão horizontal, como se procurassem atar-se ao solo para garantir o espaço comum, pois o rastejo obriga os espectadores a também se movimentarem. É o caso da cena em que os bailarinos cobrem as cabeças com peças de roupa - em novo mascaramento - e se deslocam de joelhos, apoiados nas mãos, com gritos e gemidos como se indicassem pessoas sem rosto, que sofrem anônimas. É inevitável a remissão às catástrofes e à crueldade das mortes anunciadas no país. E também à sugestão de um "curvar-se em direção à terra" para "fundá-la e torná-la densa para impedir a queda do cosmo", como nota Renan Ji (2017) em crítica do espetáculo. ${ }^{15}$ Segundo Lia Rodrigues, o que se buscava era uma dança de sobrevivência, que gritasse e evocasse forças de natureza sensível para continuar a viver e, especialmente, para tocar lugares e pessoas que o sensível consegue pôr em jogo.

14 Eirmann faz observações semelhantes a respeito das coreografias Self Unfinished, de Xavier Le Roy e Körper, de Sasha Waltz.

$15 \mathrm{Na}$ crítica do espetáculo, Voar e saber cair, Renan Ji também se refere ao "misto de técnica e transe. 
Durante toda a apresentação, o sistema sensorial dos espectadores é acionado pelo odor intenso do café e do açafrão, pelos sabores das partículas que grudam nos lábios com a poeira levantada, pelos toques dos corpos dos bailarinos que roçam o público na deambulação pelo espaço, muitas vezes, no ritmo cadenciado das batidas de pés no chão. ${ }^{16} \mathrm{~A}$ sensação é interrompida na passagem em que os dançarinos iniciam uma caminhada em direção aos espectadores. Cada um escolhe um deles para encarar de perto, com olhar intenso e perscrutador, e permanece por longos momentos sustentando e devolvendo o estranhamento com que é fitado. Mas essa situação próxima e íntima de ligação com o olhar do outro, que "às vezes confronta, às vezes convida", abre um circuito inesperado por onde "chegam esses outros, sejam os craqueiros zumbis da favela da Maré ou os ianomâmis de Davi Kopenawa" (KATZ, 2017). Depois de alguns minutos de mirada os bailarinos passam a outra pessoa, forçando o entorno a se agitar e transitar novamente. $\mathrm{Na}$ sequência, abrem espaço entre os espectadores para dirigir-se ao lado oposto do galpão, em movimento incessante de expansão e ocupação do lugar.

A deambulação permite que o espectador veja os bailarinos a partir de vários ângulos, e os reconheça como corpos em constante metamorfose, por meio de torsões, mascaramentos, gestos expandidos, desregrados, desfigurados a ponto de perder-se o sentido do que se vê. É um modo radical de estranhamento que faz contraponto ao mergulho sensorial anterior. Assim, o convite à participação nesse mundo incomum induz a uma relação ao mesmo tempo de exclusão e inclusão. "A obra solicita o espectador para o seu mundo, o inclui, mas ao mesmo tempo o exclui,", e assim impede que ele se desligue do espaço comum, externo, em que a obra tem seus apoios (LIMA, 2007, p. 102). A direção para fora mostra que, sem dúvida, há uma permeabilização da fronteira entre obra e espectador, espaço cênico e contexto. Nessa abertura, a autonomia da obra de arte é posta em questão, pois o trabalho compartilha um espaço comum e um certo ideal de comunidade artística e política. Ao mesmo tempo, ele não se apresenta como um conjunto homogêneo de identidades, sem dentro nem fora. Não se trata de uma união que congrega performers e espectadores em uma suposta microcomunidade relacional - o que implicaria vincular,

16 Tales Frey se refere à mistura de sons, cheiros e sabores na crítica Vivência conjunta para sensações dessemelhantes. 
sem mediações, estética e política. Ao contrário, é um trabalho que defende seu espaço enquanto obra precária, enquanto formalização instável que precisa fincar-se no espaço de fora para se completar. Assim, assume a reflexividade como condição necessária para proteger o artista de uma suposta dissolução no outro que, no extremo, acabaria por comprometer até mesmo a "condição de outro"' Nesse sentido, reflete a alteridade por meio de estratégias de relativização de perspectiva e alteração do outro que interrompem a percepção mútua de performers e espectadores (EIERMANN, 2012, p. 24).

Por tudo isso, a meu ver não há nas criações de Lia Rodrigues a intenção de superar a forma artística visando sua substituição por modos de relação social, na direção da estética relacional das últimas décadas. Ainda que instável, a forma dos trabalhos evita que eles se dissolvam no contexto em que se inserem a ponto de perderem estatuto próprio. Em suas formações móveis, espaço coreográfico e espaço social reconfiguram-se reciprocamente, impedindo que um se inclua e se anule no outro. Movediças, flutuantes, transformáveis a partir do encontro com o outro da favela e da floresta, configuram um modo artístico baseado na tensão entre autonomia e heteronomia, que consegue preservar a distância entre arte e práxis vital. E permite repensar a noção de autonomia da arte regida por leis internas e de heteronomia enquanto submissão da forma ao contexto exterior. Talvez seja aplicável às experiências de Lia Rodrigues e sua companhia a noção de "heteronomia sem servidão" que chamei, no princípio dessa análise, de autonomia dissidente. Para Jacques Derrida (2007), ela não é a regulação da forma por uma exterioridade soberana, mas sua incorporação e transfiguração na interioridade mesma da própria forma. ${ }^{17}$

\section{Referências bibliográficas}

ARDENNE, P. Un art contextuel. Paris: Flammarion, 2004.

BERNARDET, J. C. O processo como obra. Folha de S.Paulo, São Paulo, 13 jul. 2003. BIEDERMAN, I. A dança política de Lia Rodrigues. Folha de S.Paulo, São Paulo, 12 mar. 2017.

17 Empresto a relação entre autonomia, heteronomia e heteronomia sem servidão do texto inédito de Ricardo Fabbrini, A poética de risco do teatro da Vertigem, a ser publicado no livro sobre os 25 anos do grupo. 
BIET, C.; TRIAU, C. Qu'est-ce que le théâtre? Paris: Gallimard, 2006. p. 838-839.

BISHOP, C. Artificial hells. Participatory art and the politics of spectatorship. Nova York: Verso, 2012a.

Participation and spectacle: where are we now? In: Living as form:

Socially engaged art from 1991-2011. Cambridge: MIT Press, 2012b. p. 34-45.

BOURRIAUD, N. Estética relacional. Trad. Denise Bottmann. São Paulo: Martins Fontes, 2009.

Radicante. Trad. Dorothée de Bruchard. São Paulo: Martins Fontes, 2011.

CARTER, P. The lie of the land. Boston: Faber\&Faber, 1996.

CASTRO, E. V. O recado da mata. In: KOPENAWA, D.; ALBERT, B. A queda do céu.

São Paulo: Companhia das Letras, 2010.

CORNAGO, O. [Ser uno/ser muchos]. Comunidades sin nombre. In:

Ensayos de teoria escénica: Sobre teatralidad, público y democracia. Madri: Abada, 2015.

DEBORD, G. A sociedade do espetáculo. Trad. Estela dos Santos Abreu. Rio de Janeiro: Contraponto, 1997.

DELEUZE, G. Um manifesto de menos. In: Sobre o teatro. Trad. Fátima

Saadi, Ovídio de Abreu, Roberto Machado. Rio de Janeiro: Zahar, 2010. p. 25-64. DERRIDA, J. Força da lei: o fundamento místico da autoridade. São Paulo: Martins Fontes, 2007.

DIÉGUEZ, I. Um teatro sem teatro: a teatralidade como campo expandido. Sala

Preta, São Paulo, v. 14, n. 2, p. 125-129, 2014.

EIERMANN, A. El teatro postspectacular. Telefondo - Revista de Teoria y Critica

Teatral, Buenos Aires, n. 16, p. 1-24, dez. 2012.

FABBRINI, R. A poética de risco do teatro da Vertigem. In: FERNANDES, S. (Org.).

Teatro da Vertigem: 25 anos. Rio de Janeiro: Cobogó, no prelo.

FREY, T. Vivência conjunta para sensações dessemelhantes. eRevista Performatus, Inhumas, ano 6, n. 19, jan. 2018.

FRIED, Michael. Absorption and theatricality: painting and beholder in the age of Diderot. Chicago: The University of Chicago Press, 1980.

Art and objecthood. Chicago: The University of Chicago Press, 1998.

Contre la théâtralité: du minimalisme à la photographie contemporaine.

Paris: Gallimard, 2007.

FROTA, G. O ritual de Lia Rodrigues para manter o céu lá em cima. O Público,

Lisboa, 13 dez. 2017.

GALHÓS, C. Segurar o céu. Expresso, Paço de Arcos, 8 dez. 2017.

GIRAUD, V. Lia Rodrigues, Pour que le ciel ne tombe pas. Naja 21: Le journal des créations du 21e., [S.I], 2 jul. 2016.

JACOMINO, D. Para que o céu não caia em nossas cabeças, Swissinfo.ch, [S.I.], 5 set. 2017. Disponível em: <https://bit.ly/2Ht6Qrv>. Acesso em: 7 jun. 2018. 
JACQUES, P. B. Apologia da deriva: escritos situacionistas sobre a cidade. Rio de Janeiro: Casa da Palavra, 2003.

JI, R. Voar e saber cair. MITsp.org., São Paulo, 18 mar. 2017. Disponível em: <https:// bit.ly/2sQgxet>. Acesso em: 7 jun. 2018.

KATZ, H. Para que o céu não caia guarda a fórmula da dança. O Estado de S. Paulo, São Paulo, 28 mar. 2017.

KOPENAWA, D.; ALBERT, B. A queda do céu. São Paulo: Companhia das Letras, 2010.

LEPECKI, A. Coreopolítica e coreopolícia. Ilha, Florianópolis, v. 13, n. 1, p. 41-60, jan./jun. 2012.

. From partaking to initiating: leadingfollowing as dance's (a-personal) political singularity. In: SIEGMUND, G.; HÖLSCHER, S. Dance, politics \& co-immunity. Zurique: Diaphanes, 2013.

LIMA, D. Corpo, política e discurso na dança de Lia Rodrigues. Rio de Janeiro: UniverCidade, 2007.

NÉSPOLI, B. Para escutar o som da floresta. Teatro Jornal, [S.I.], 22 mar. 2017.

PAVLOVA, A. Encarnado: uma leitura coreopolítica do projeto de Lia Rodrigues na Favela da Maré. Dança, Salvador, v. 4, n. 2, p. 65-75, jul./dez. 2015.

Passos da Maré para o mundo. Intercâmbios e parcerias marcam o dia a dia da Escola Livre de Dança da Maré. Redes da Maré, Rio de Janeiro, 6 jun. 2017. Disponível em: <https://bit.ly/2M4nvVU>. Acesso em: 7 jun. 2018.

RANCIÈRE, J. Le tournant éthique de l'esthétique et de la politique. In:

Malaise dans l'esthétique. Paris: Galilée, 2004. p. 145-173.

Paradoxos da arte política. In:

0 espectador emancipado. Trad. Ivone C. Benedetti. São Paulo: Martins Fontes, 2012. p. 51-81.

SIEGMUND, G. Partager l'absence. In: Être ensemble: figures de la communauté en danse depuis le XXe siècle. Paris: Centre national de la danse, 2003. p. 321-334.

SILVA, E. S. Testemunhos da Maré. Rio de Janeiro: Aeroplano; Faperj, 2012.

SOTER, S. Um pé dentro e um pé fora: passos de uma dramaturga. In: NORA, S.

(Org.). Temas para a dança brasileira. São Paulo: Sesc, 2010.

TRIAU, C. L'illusion ludique. Théâtre/Public, Gennevilliers, n. 194, p. 33-38, 2009.

Recebido em 03/06/2018

Aprovado em 05/06/2018

Publicado em 29/06/2018 